\title{
Türki Cumhuriyetlerde Elektrik Tüketimi, Reel Gelir ve Dışa Açıkık İlişkisi: Bootstrap-Granger Nedensellik Yaklaşımı
}

\author{
Ali ACARAVCI ${ }^{1}$ \\ Sinan ERDOĞAN ${ }^{2}$
}

ÖZ: Bu çalışma, Türki Cumhuriyetlerde reel gelir, elektrik enerji tüketimi ve dışa açıklık arasındaki nedensellik ilişkilerini, yatay-kesit bağımlılı̆̆l dikkate alan ikinci nesil panel veri yöntemleri kullanılarak 1992-2012 dönemi için araştırmaktadır. Yatay kesit bağımlılık test sonuçlarına göre, tüm değişkenler ve model yatay kesit bağımlıdır. Smith vd. Bootstrap (2004) birim kök testi sonuçlarına göre kişi başı gelir ve dışa açıklık değişkenleri düzeyde, elektrik tüketimi değişkeni ise fark durağandır. Bu nedenle değişkenler arasında uzun dönemli ilişkilerin varlığını test etmeye yönelik olarak eşbütünleşme testleri uygulanmamıştır. Değişkenler arasındaki nedensellik ilişkileri, yatay kesit bă̆ımlılı̆̆ dikkate alan, ülke bazlı sonuçlar elde etmeye olanak sağlayan ve iki açıklayıcı değişkenin bağıml değişken üzerindeki etkisini aynı anda test etmeye olanak sağlayan Konya (2006) panel nedensellik modeliyle incelenmiştir. Analiz sonuçları şu şekilde özetlenebilir: i) Elektrik tüketimi ve gelir arasında nedensellik ilişkisi mevcuttur. ii) Dışa açıklık ve gelir arasında nedensellik ilişkisi mevcuttur. iii) Enerji tüketimi ve dışa açıklık değişkenleri, gelir üzerinde daha güçlü ortak etkiye sahiptir.

Anahtar Kelimeler: Enerji, Elektrik Tüketimi, Dışa Açıklık, Bootstrap-Granger Nedensellik.

JEL Kodu: Q43, F13, O40

\section{The Relationship between Electricity Consumption, Real Income and Trade Openness in Turkic Republics: Bootstrap-Granger Causality Approach}

\begin{abstract}
This study explores the causal relationships between electricity consumption, real income and trade openness in Turkic Republics for 1992-2012 period by using second generation panel data methods under cross-sectional dependence. According to cross-sectional dependence tests, all variables and model are cross-sectionally dependent. According to the Smith et al. (2004) bootstrap unit root test, real income per capita and trade openness variables are stationary on level. On the contrary, electricity consumption variable is stationary in first difference. Therefore, cointegration tests have not been implemented in order to long-run relationships between variables. Causal relationships between variables have been examined by using Konya (2006) panel data causality approach which allows cross-sectional dependence and gives possibility to examine two explanatory variables' effects on dependent variable and obtain country-specific results. The results can be summarized as follows: i) There exist a causal relationship between electricity consumption and real income. ii) There exist a causal relationship between trade openness and real income. iii) Electricity consumption and trade openness variables have more powerful common effects on real income.
\end{abstract}

Key Words: Energy, Electricity Consumption, Trade Openness, Bootstrap-Granger Causality. JEL Codes: Q43, F13, O40

Geliş Tarihi / Received: 05/07/2017

Kabul Tarihi / Accepted: 13/09/2017

\footnotetext{
* Bu çalışma, 1.Uluslararası Al-Farabi Sosyal Bilimler Kongresinde Sözlü Olarak Sunulmuştur.

1 Prof. Dr., Mustafa Kemal Üniversitesi, İktisadi ve İdari Bilimler Fakültesi, İktisat Bölümü, acaravci@mku.edu.tr, orcid.org/0000-0002-6662-6175

2 Arş. Gör., Mustafa Kemal Üniversitesi, İktisadi ve İdari Bilimler Fakültesi, İktisat Bölümü, sinanerdogan@mku.edu.tr, orcid.org/0000-0003-3491-8234
} 


\section{Giriș}

Enerji tüketimi ve ekonomik büyüme ilişkisi, Kraft ve Kraft 'in 1978 yılında yayınlanan çalışmasından bu yana iktisat biliminde ilgi çeken çalışma alanı olmuştur. Bu bağlamda enerji tüketimi ve iktisadi büyüme ilişkisine dair çeşitli paradigmalar oluşturulmuştur. Enerji tüketimi ve ekonomik büyüme arasındaki ilişkiler üzerine odaklanan bu paradigmalardan "Yansızlık Hipotezi (Neutrality Hypothesis)" yaklaşımına göre elektrik tüketimi ve iktisadi büyüme arasında herhangi bir ilişki bulunmamaktadır. "Koruma Hipotezi (Conservation Hypothesis)" yaklaşımına göre ekonomik büyümeden elektrik tüketimine doğru tek yönlü bir ilişki bulunmakta olup politikalar elektrik tüketiminin azaltılmasına yönelik olarak şekillendirilmektedir ve bu politikalar ekonomik büyüme üzerinde herhangi etkiye sahip değildir. "Büyüme Hipotezi (Growth Hypothesis)" yaklaşımına göre elektrik tüketiminden ekonomik büyümeye doğru tek yönlü bir ilişki bulunmakta olup, elektrik tüketimi arttıkça ekonomik büyüme de artmaktadır. $\mathrm{Bu}$ bağlamda elektrik tüketimini azaltmaya yönelik olarak uygulanacak politikalar ekonomik büyümeyi yavaşlatacaktır. Son olarak "Geri Besleme Hipotezi (Feedback Hypothesis)" yaklaşımına göre ise elektrik tüketimi ve ekonomik büyüme arasında çift yönlü bir ilişki mevcut olup, ekonomik büyüme veya elektrik tüketiminde yaşanacak değişimler karşılıklı olarak birbirini etkilemektedir (Jumbe, 2004).

İzleyen dönemde elektrik tüketimi ve ekonomik büyüme ilişkisi konusunda yapılan çalışmaların sayısı artmış ve bu alanda kayda değer bir literatür oluşmuştur. Elektrik tüketimi ve iktisadi büyüme ilișkisini inceleyen bir çok çalışma olmakla beraber öne çıkan çalışmalar literatür tablosunda sunulmuştur. Tablo genel olarak incelendiğinde, çalışmalar ağırlıklı olarak büyüme hipotezini destekler nitelikte sonuçlara ulaşmıştır. Diğer taraftan bir kısım çalışmalar yansızlık hipotezi, koruma hipotezi ve geri besleme hipotezini destekleyen sonuçlara ulaşmıştır. $\mathrm{Bu}$ bağlamda elektrik tüketimi ve iktisadi büyüme arasındaki ilişkinin yönü konusunda tam bir uzlaşı olmadığı görülmektedir. Bu bağlamda enerji tüketimi ve ekonomik büyüme ilişkisinin net olarak ortaya konulabilmesi, enerji arz politikalarının ve iktisadi büyüme stratejilerinin oluşturulması adına önem kazanmaktadır.

Sovyetler Birliğinin dağılmasıyla liberal demokrasiler hem politik hem de iktisadi açıdan ideolojik zaferini ilan etmiş ve bu durum Sovyet bloğuna mensup ülkelerde kumanda ekonomilerinin dönüştürülmesini teşvik etmiştir. Bu bağlamda "Geçiş Ekonomileri (Transitition Economies)" kavramı iktisat literatüründe sıkça tartış1ır hale gelmiştir. Genel tanımıyla katı merkeziyetçi planlamadan serbest piyasa temelli ekonomik modele geçiş aşamasında olan ülkeler, geçiş ekonomileri olarak anılmaktadır. Geçiş aşamasının temel unsurları liberalleşme, makro iktisadi istikrar, yeniden yapılandırma ve özelleştirme, yasal ve kurumsal düzenlemeler olmak üzere 4 başlık altında toplanabilir. Türkiye açısından tarihi, kültürel ve iktisadi açıdan öneme sahip olan Türki Cumhuriyetler de IMF (International 
Monetary Fund) tarafından yapılan sınıflandırmaya göre geçiş ekonomileri arasinda varsayılmaktadir (International Monetary Fund, 2000). 90'l1 yıllardan sonra değişen paradigmayla beraber dönüşüm sürecine giren Türki Cumhuriyetler, başta ticaret alanında olmak üzere dalgalı bir iktisadi dönüşüm sürecine girmiştir.

Tablo1: Literatür Tablosu

\begin{tabular}{|c|c|c|c|}
\hline Yazar (lar) & Dönem & Yöntem & Sonuç \\
\hline Murray ve Nan (1996) & $1950-1970$ & $\begin{array}{c}\text { Granger Nedensellik, } \\
\text { VAR }\end{array}$ & $E L C \rightarrow G D P$ \\
\hline Altınay ve Karagöl (2005) & $1950-2000$ & $\begin{array}{l}\text { Granger Nedensellik, } \\
\text { Dolado-Lutkepohl } \\
\text { Nedensellik }\end{array}$ & $E L C \rightarrow G D P$ \\
\hline Aktaş ve Y1lmaz (2008) & $1970-2004$ & Granger Nedensellik & $\begin{array}{l}E L C \rightarrow G D P(\mathrm{KD}) \\
G D P \rightarrow E L C(\mathrm{UD})\end{array}$ \\
\hline Erbaykal (2008) & $1970-2003$ & ARDL Yöntemi & $E L C \rightarrow G D P$ \\
\hline Narayan ve Prasad (2008) & $1960-2002$ & $\begin{array}{l}\text { Bootstrap- Granger } \\
\text { Nedensellik } \\
\text { Johansen }\end{array}$ & $E L C \neq G D P$ \\
\hline Acaravc1 (2010) & $1968-2010$ & $\begin{array}{c}\text { Eşbütünleşme, } \\
\text { Granger Nedensellik }\end{array}$ & $E L C \rightarrow G D P$ \\
\hline Acaravcı ve Öztürk (2012) & 1968-2006 & $\begin{array}{l}\text { Granger Nedensellik, } \\
\text { ARDL Yöntemi }\end{array}$ & $E L C \rightarrow G D P$ \\
\hline Aslan (2013) & $1968-2008$ & $\begin{array}{l}\text { Granger Nedensellik, } \\
\text { ARDL Yöntemi, } \\
\text { VECM }\end{array}$ & $\begin{array}{c}E L C \neq G D P(\mathrm{KD}) \\
E L C \leftrightarrow G D P(\mathrm{UD})\end{array}$ \\
\hline Nazlıoğlu vd. (2014) & $1967-2007$ & $\begin{array}{l}\text { Granger Nedensellik, } \\
\text { ARDL Yöntemi, } \\
\text { VECM }\end{array}$ & $\begin{array}{l}E L C \leftrightarrow G D P(\mathrm{LA}) \\
E L C \neq G D P(\mathrm{NLA})\end{array}$ \\
\hline Pempetzoglou (2014) & 1945-2006 & $\begin{array}{l}\text { Diks ve Pankchenko } \\
\text { Nedensellik }\end{array}$ & $E L C \rightarrow G N P$ \\
\hline Aslan (2014) & $1980-2008$ & $\begin{array}{l}\text { Granger Nedensellik, } \\
\text { ARDL Yöntemi }\end{array}$ & $\begin{array}{l}E L C \leftrightarrow G D P(\mathrm{KD}) \\
E L C \rightarrow G D P(\mathrm{UD})\end{array}$ \\
\hline Acaravcı vd. (2015) & $1974-2013$ & $\begin{array}{l}\text { Granger Nedensellik, } \\
\text { ARDL Yöntemi }\end{array}$ & $E L C \rightarrow G D P$ \\
\hline Iyke (2015) & $1971-2011$ & VECM & $E L C \rightarrow G D P$ \\
\hline Ibrahiem (2015) & $1980-2011$ & $\begin{array}{l}\text { Granger Nedensellik, } \\
\text { ARDL Yöntemi }\end{array}$ & $E L C \leftrightarrow G D P$ \\
\hline Salahuddin ve Alam (2016) & $1985-2012$ & $\begin{array}{l}\text { Dumitrescu-Hurlin } \\
\text { Nedensellik Testi }\end{array}$ & $E L C \rightarrow G D P$ \\
\hline
\end{tabular}

Not: $\rightarrow$ Tek yönlü ilişkiyi, $\leftrightarrow$ çift yönlü ilişkiyi, $\neq$ ise ilişki olmadığını ifade etmektedir. KD= Kısa Dönem, UD= Uzun Dönem. LA= Lineer Analiz. NLA= Non-Lineer Analiz.

Grafik 1'de de görüldüğü üzere ticari açıklık konusunda dalgalı bir süreç deneyimleyen Türki Cumhuriyetlerde, dönüşüm sürecinin içinde bulunulan dönemin koşullarından etkilendiği de söylenebilir. 
Grafik 1: Türki Cumhuriyetlerde Ticari Açılık

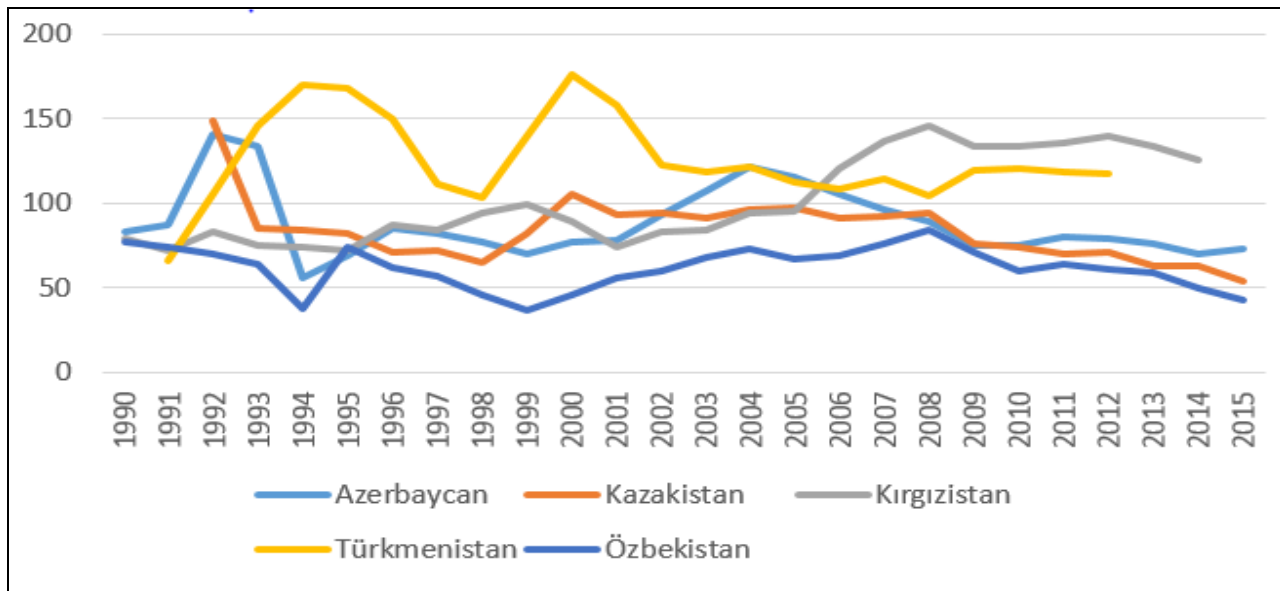

Kaynak: Dünya Bankası Dünya Gelişme Göstergeleri Çevrimiçi Veri Tabanı verileri kullanılarak tarafımızca hazırlanmıştır.

Yaşanan iktisadi dönüşüm sürecinin etkileri Türki Cumhuriyetlerde enerji tüketimini de etkilemiştir. Grafik 2'de de görüldüğü üzere 90'l1 yılların ilk yarısında düşüş gösteren enerji talebi, 2000'li yıllara gelindiğinde dalgalı da olsa artmış ve son dönemlerde yukarı yönlü yumuşak bir trend yakalamıştır. Ticari açıklığa bağlı olarak artması beklenen ihracat, teknoloji transferi ve bilgi teknolojileri kullanım oranları, enerji talebi artışını teşvik etmiştir.

Grafik 2: Türki Cumhuriyetlerde Kişi Başı Elektrik Tüketimi

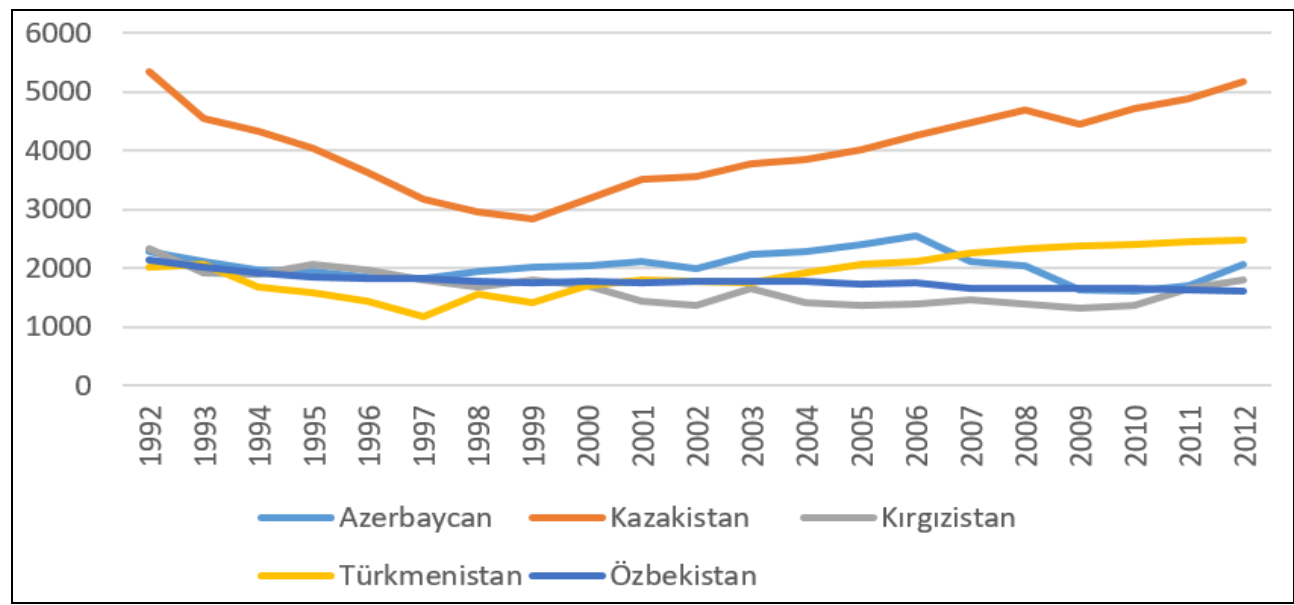

Kaynak: Dünya Bankası Dünya Gelişme Göstergeleri Çevrimiçi Veri Tabanı verileri kullanılarak tarafımızca hazırlanmıştır.

Bu bağlamda Türki Cumhuriyetlerde enerji tüketimi, ticari açıklık ve ekonomik büyüme ilişkisinin ortaya konması, hem etkin enerji arz ve talep politikalarının oluşturulmasına hem de dönüşüm sürecinin iktisadi etkilerinin irdelenmesi adına önem arz etmektedir. Bu amaçla çalışmada Türki Cumhuriyetlerde elektrik 
tüketimi, ticari açıklık ve reel gelir arasındaki ilişkiler 1992-2012 dönemi için incelenmiş olup çalışmanın ikinci kısmında model ve örneklem açıklanmış, üçüncü kısımda kullanılan yöntemler ve ampirik bulgular irdelenmiş olup dördüncü kısımda sonuç ve politika önerileri yer almaktadır.

\section{Model ve Örneklem}

$\mathrm{Bu}$ çalışmada Türkiye ile iktisadi, tarihi ve kültürel bağları bulunan Türki Cumhuriyetlerde (Azerbaycan, Kazakistan, Kırgızistan, Türkmenistan, Özbekistan) elektrik tüketimi, ticari açıklık ve reel gelir ilişkisi 1992-2012 dönemi için yatay kesit bağımlılığı dikkate alan panel veri yöntemleri kullanılarak araştırılmıştır. Değişkenler arasındaki nedensellik ilişkisini test etmek amacıyla, yatay kesit bağımlılığı da dikkate alan aşağıdaki Bootstrap-Granger nedensellik modeli kullanılmıştır:

$$
G D P_{N t}=\alpha_{1 N}+\sum_{l=1}^{p_{1}} \beta_{1 N l} G D P_{N t-l}+\sum_{l=1}^{p_{1}} \delta_{1 N l} E C_{N t-l}+\sum_{l=1}^{p_{1}} \varphi_{1 N l} T R_{N t-l}+\varepsilon_{11 t}
$$

Burada $\mathrm{N}=1,2, \ldots 5$ ve $\mathrm{t}=1,2, \ldots 22$ 'dir. Burada, $G D P$ değişkeni kişi başına reel geliri göstermektedir. Ayrıca $E C$ değişkeni kişi başı elektrik tüketimini, TR değişkeni ise ticari açıklığ ifade etmektedir. Veri seti, 1992-2012 yıllarını kapsayan eksiksiz verilerden oluşmaktadır. Tüm değişkenler Dünya Bankası Dünya Gelişme Göstergeleri çevrimiçi veri tabanından (World Bank World Development Indicators Online Database) alınmıştır. Tüm değişkenlerin doğal logaritması alınmış ve doğrusallaştırılmıştır.

\section{Yöntem ve Ampirik Bulgular}

Panel veri analizinde birim kök testleri, değişkenler arasında bulunabilecek yatay kesit bağımlılık özelliklerine duyarlıdır. $\mathrm{Bu}$ nedenle panel veri modellerinde değişkenler arasında oluşabilecek yatay kesit bağımlılık ilişkileri araştırılmalıdır. Değişkenlerde veya modelde oluşabilecek yatay kesit bağımlılık özelliklerinin göz ardı edilmesi sapmalı tahminlere neden olabilmektedir. Bu bağlamda modelde yer alan değişkenler ve kurulan modelin yatay kesit bağımlılık özellikleri Pesaran'ın (2004) CD testi ile araştırılmıştır. Ayrıca denklemlerde hesaplanacak olan eğim katsayılarının homojenliğini test etmeye yönelik olarak Pesaran ve Yamagata (2008) tarafından geliştirilen delta testleri kullanılmıştır. Yatay kesit bağımlılık (a) ve homojenlik (b) testlerinde, test edilen hipotezler sırasıyla aşağıdaki gibidir:

$$
H_{0}=\text { Yatay Kesit Bă̆ımlılık Yoktur. (a) } \quad C D=\sqrt{\frac{2 T}{N(N-1)}}\left\{\sum_{i=1}^{N-1} \sum_{j=i+1}^{N} \stackrel{\Lambda}{p i j}\right\}
$$

$H_{1}=$ Yatay Kesit Băğmlılık Vardır.

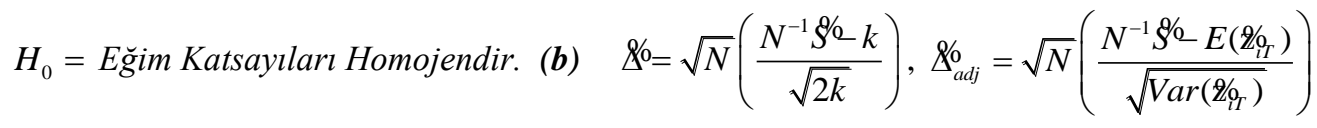

$H_{1}=$ Ĕ̈im Katsayıları Heterojendir. 
Yatay kesit bağımlılık test sonuçları ve eğim katsayılarının homojenliğini test etmeye yönelik olarak uygulanan delta testlerinin sonuçları Tablo 2 de sunulmuştur. Sonuçlara göre, değişkenlerde ve modelde yatay kesit bağımlılık olmadığı hipotezi $\% 5$ anlamlılık düzeyinde reddedilmektedir. Buna göre analize dâhil edilen ülkelerde, değişkenlerden birinde görülecek bir artış veya azalış diğer ülkeleri de etkilemektedir. Homojenlik testlerine göre hesaplanan eğim katsayılarının homojen olduğu hipotezi $\% 5$ anlamlılık düzeyinde reddedilmektedir.

Tablo 2: Yatay Kesit Bağımlılık ve Katsayı Homojenliği Test Sonuçları

\begin{tabular}{lcccc}
\hline & GDP & $\boldsymbol{E C}$ & $\boldsymbol{T R}$ & Model \\
\hline CD Test & -2.176 & $2.018(0.022)$ & -2.796 & $3.845(0.000)$ \\
\hline Delta Tilde & $(0.015)$ & & $(0.003)$ & \\
Delta Tilde Adj & & & & $8.151(0.000)$ \\
\hline
\end{tabular}

Not: Parantez içindeki değerler, olasılık değerleridir.

Değişkenler ve modelin yatay kesit bağımlılık içermesi, değişkenlerin durağanlık özelliklerinin araştırılması ve nedensellik ilişkilerinin araştırılması noktasında yatay kesit bağımlılığı dikkate alan ikinci nesil testlerin kullanılmasını zorunlu kılmaktadır. $\mathrm{Bu}$ nedenle değişkenlerin durağanlık özelliklerinin araştırılması amacıyla yatay kesit bağımlılı̆̆1 dikkate Smith vd. (2004) birim kök testi uygulanmış ve Tablo 3'te sunulmuştur. Smith vd. (2004) testi, yöntemsel olarak Im vd. (2003) tarafından geliştirilen birim kök testine dayanmaktadır. Yöntem kapsamında yatay kesit bağımlılık bootstap yaklaşımı ile modellenmektedir ve $\mathrm{t}$ istatistikleri bireysel ADF istatistiklerinin ortalaması ile elde edilmektedir. Standartlaştırılmış $\mathrm{t}$ istatistiği ise 5 numaralı denklemde gösterildiği gibi elde edilmektedir. Model kapsamında test edilen hipotezler aşağıdaki gibidir:

$$
\begin{array}{ll}
H_{0}=\text { Birim Kök Vardır. } & t^{*}=N^{-1} \sum_{i=1}^{N} t_{i} \\
H_{1}=\text { Birim Kök Yoktur. } & \bar{t}_{s}=\frac{\sqrt{N}\left\{\bar{t}-E\left(t_{i}\right)\right\}}{\left.\sqrt{\operatorname{Var}\left(t_{i}\right.}\right)}
\end{array}
$$

Birim kök testi sonuçlarına göre bağımlı değişken kişi başı gelir serisi sabitli modelde birim kök içermekte ve fark durağan iken trend ve sabitli modelde düzeyde durağandır. $\mathrm{Bu}$ nedenle değişkenler arasında eşbütünleşme ilişkileri incelenmemiştir. Diğer taraftan elektrik tüketimi değişkeni hem sabitli hem de trend ve sabitli modelde birim kök içermekte olup fark durağandır. Ticari açıklık değişkeni ise hem sabitli hem de trend ve sabitli modelde düzeyde durağandır.

Gerek değişkenlerin ve modelin yatay kesit bağımlılık içermesi gerekse hesaplanacak olan katsayıların heterojen olduğu görüşü, yatay kesit bağımlılığı 
dikkate alan ve heterojen katsayıların hesaplanmasına olanak sağlayan testlerin kullanılmasını zorunlu kılmaktadır. Bu amaçla değişkenler arasında nedensellik ilişkilerini test etmek amacıyla Konya (2006) tarafından geliştirilen, metodolojik olarak Granger nedensellik testine dayanan ve yatay kesit bağımlığı bootstrap yöntemiyle modelleyen nedensellik testi kullanılmıştır.

Tablo 3: Smith vd. Bootstrap Panel Birim Kök Test Sonuçları

\begin{tabular}{lcccc}
\hline \multirow{2}{*}{ Model } & \multicolumn{2}{c}{ Düzey } & \multicolumn{2}{c}{ 1. Fark } \\
\cline { 2 - 5 } & Sabit & Trend ve Sabit & Sabit & $\begin{array}{c}\text { Trend ve } \\
\text { Sabit }\end{array}$ \\
\hline Değişkenler & IPS İstatistiği & IPS İstatistiği & $\begin{array}{c}\text { IPS } \\
\text { İstatistiği }\end{array}$ & $\begin{array}{c}\text { IPS } \\
\text { İstatistiği }\end{array}$ \\
\hline GDP & $-0.674(0.868)$ & $-4.039(0.000)$ & -3.359 & - \\
& & & $(0.000)$ & $-4.090(0.000)$ \\
EC & $-2.146(0.067)$ & $-2.336(0.303)$ & -3.757 & - \\
TR & $-2.859(0.003)$ & $-3.518(0.008)$ & $-0.000)$ & - \\
\hline
\end{tabular}

Not: Gecikme uzunluğu 2 olarak alınmış olup olasılık değerleri 10.000 bootstrap dağılımından elde edilmiş ve parantez içinde gösterilmiştir

Öncelikle elektrik tüketiminden kişi başı reel gelire doğru nedensellik ilişkisi incelenmiş olup sonuçlar Tablo 4'te sunulmuştur. Sonuçlara göre, Kazakistan ve Özbekistan'da elektrik tüketiminden kişi başı reel gelire bir nedensellik ilişkisi olmadığına dair test edilen yokluk hipotezi \%1 anlamlılık düzeyinde reddedilmiştir. Buna göre bu iki ülkede elektrik tüketiminden kişi başı reel gelire doğru nedensellik ilişkisi söz konusudur.

Tablo 4: Konya Nedensellik Testi Sonuçları

\begin{tabular}{lcccc}
\hline & $H_{0}:$ EC, GDP'nin Nedeni Değildir \\
\cline { 2 - 5 } & İstatistik & \multicolumn{3}{c}{ Kritik Değerler } \\
\cline { 3 - 5 } & & $\mathbf{1 0 \%}$ & $\mathbf{5 \%}$ & $\mathbf{1 \%}$ \\
\hline Azerbaycan & 1.968 & 4.749 & 7.191 & 13.568 \\
Kazakistan & $36.042^{*}$ & 4.568 & 6.674 & 12.463 \\
Kırgizistan & 4.795 & 4.834 & 7.271 & 14.253 \\
Türkmenistan & 0.493 & 4.497 & 7.041 & 14.681 \\
Özbekistan & $27.058^{*}$ & 3.973 & 5.898 & 11.412 \\
\hline
\end{tabular}

Not: Kritik değerler 10.000 bootstrap tekrarından elde edilmiştir. *** \%10 anlamlılık düzeyinde, ** \%5 anlamlılık düzeyinde, * ise $\% 1$ anlamlılık düzeyinde istatistiksel olarak anlamlılığı ifade etmektedir.

Ticari açıklık ve kişi başı reel gelir arasındaki nedensellik test sonuçları Tablo 5'te sunulmuştur. Buna göre ticari açıklık kişi başı reel gelirin nedeni olmadığına dair test edilen yokluk hipotezi, Kırgızistan için \%1, Türkmenistan için ise $\% 5$ anlamlılık düzeyinde reddedilmiştir. Buna göre bu ülkelerde ticari açıklıktan kişi başı reel gelire doğru nedensellik ilişkisi söz konusudur. 
Tablo 5: Konya Nedensellik Testi Sonuçları

\begin{tabular}{lcccc}
\hline & $H_{0}:$ TR, GDP'nin Nedeni Değildir \\
\cline { 2 - 5 } & İstatistik & \multicolumn{3}{c}{ Kritik Değerler } \\
\cline { 2 - 5 } & & $\mathbf{1 0 \%}$ & $\mathbf{5 \%}$ & $\mathbf{1 \%}$ \\
\hline Azerbaycan & 1.862 & 4.945 & 7.392 & 14.089 \\
Kazakistan & 0.176 & 5.024 & 7.354 & 14.767 \\
Kurgizistan & $15.971^{*}$ & 4.550 & 6.629 & 12.411 \\
Türkmenistan & $11.10^{* *}$ & 5.066 & 7.309 & 14.622 \\
Özbekistan & 0.261 & 4.689 & 6.699 & 13.162 \\
\hline
\end{tabular}

Not: Kritik değerler 10.000 bootstrap tekrarından elde edilmiştir. *** \%10 anlamlılık düzeyinde, $* * \% 5$ anlamlılık düzeyinde, $*$ ise $\% 1$ anlamlılık düzeyinde istatistiksel olarak anlamlılı̆̆ 1 ifade etmektedir.

Konya (2006) nedensellik testi, iki açıklayıcı değişken ile bağımlı değişken arasındaki nedensellik ilişkisini test etmeye olanak sağlamaktadır. Bu bağlamda elektrik tüketimi, ticari açıklık ve kişi başı reel gelir değişkeni arasındaki nedensellik ilişkileri Tablo 6'da sunulmuştur. Buna göre Kazakistan, Kırgızistan ve Özbekistan'da elektrik tüketimi ve ticari açıklığın kişi başı reel gelir arasında nedensellik ilişkisi olmadığına dair yokluk hipotezi \%1 anlamlılık düzeyinde reddedilmektedir. Buna göre ilgili ülkelerde elektrik tüketimi ve ticari açıklıktan kişi başı reel gelire doğru bir nedensellik ilişkisi söz konusudur.

Tablo 6: Konya Nedensellik Testi Sonuçları

\begin{tabular}{lcccc}
\hline & \multicolumn{3}{c}{$H_{0}:$ EC ve TR, GDP'nin Nedeni Değildir } \\
\cline { 2 - 5 } & İstatistik & \multicolumn{3}{c}{ Kritik Değerler } \\
\cline { 2 - 5 } & & $\mathbf{1 0 \%}$ & $\mathbf{5 \%}$ & $\mathbf{1 \%}$ \\
\hline Azerbaycan & 1.458 & 4.435 & 6.731 & 12.923 \\
Kazakistan & $32.991^{*}$ & 5.127 & 7.377 & 14.563 \\
Kurgizistan & $26.503^{*}$ & 4.370 & 6.446 & 13.228 \\
Türkmenistan & 1.682 & 4.634 & 6.966 & 13.672 \\
Özbekistan & $33.867^{*}$ & 4.088 & 5.997 & 11.635 \\
\hline
\end{tabular}

Not: Kritik değerler 10.000 bootstrap tekrarından elde edilmiştir. *** \%10 anlamlılık düzeyinde, ** \%5 anlamlılık düzeyinde, * ise $\% 1$ anlamlılık düzeyinde istatistiksel olarak anlamlılığı ifade etmektedir.

Son olarak kişi başı reel gelirden elektrik tüketimine doğru nedensellik ilişkisi test edilmiş olup sonuçlar Tablo 7'de sunulmuştur. Buna göre kişi baş1 reel gelirin, elektrik tüketimi değișkeninin nedeni olmadığına dair test edilen yokluk hipotezi Kazakistan'da \%1, Türkmenistan ve Özbekistan'da \%5 anlamlılık düzeyinde reddedilmiştir. Buna göre bu ülkelerde kişi başı gelirden elektrik tüketimine doğru bir nedensellik ilişkisi söz konusudur. 
Tablo 7: Konya Nedensellik Testi Sonuçları

\begin{tabular}{lcccc}
\hline & $H_{0}:$ GDP, EC'nin Nedeni Değildir \\
\cline { 2 - 5 } & İstatistik & \multicolumn{3}{c}{ Kritik Değerler } \\
\cline { 3 - 5 } & & $\mathbf{1 0 \%}$ & $\mathbf{5 \%}$ & $\mathbf{1 \%}$ \\
\hline Azerbaycan & 1.145 & 3.886 & 5.684 & 10.615 \\
Kazakistan & $32.645^{*}$ & 4.021 & 5.924 & 11.376 \\
Kurgizistan & 0.727 & 4.217 & 5.948 & 11.050 \\
Türkmenistan & $9.912^{* *}$ & 4.081 & 5.720 & 11.055 \\
Özbekistan & $5.758^{* *}$ & 3.833 & 5.668 & 10.929 \\
\hline
\end{tabular}

Not: Kritik değerler 10.000 bootstrap tekrarından elde edilmiştir. *** \%10 anlamlılık düzeyinde, ** \%5 anlamlılık düzeyinde, * ise $\% 1$ anlamlılık düzeyinde istatistiksel olarak anlamlılığı ifade etmektedir.

\section{Sonuç}

Bu çalışmada Türkiye açısından tarihi, kültürel ve iktisadi açıdan öneme sahip, aynı zamanda karşılıklı pazar alternatifi olan Türki Cumhuriyetlerde elektrik tüketimi, ticari açıklık ve ekonomik büyüme ilişkisi 1992-2012 dönemi için, yatay kesit bağımlılığı dikkate alan ikinci nesil panel veri yöntemleri kullanılarak araştırılmıştır. Çalışma kapsamında elde edilen sonuçlar aşağıdaki gibi özetlenebilir:

i) Yatay kesit bağımlılık ve homojenlik testlerine göre tüm değişkenler ve model yatay kesit bağımlı olup, hesaplanacak olan katsayılar heterojendir. ii) Birim kök testi sonuçlarına göre bağımlı değişken kişi başı reel gelir sabitli modelde birim kök içermekte ve fark durağan iken trend ve sabitli modelde düzeyde durağandır. $\mathrm{Bu}$ nedenle değişkenler arasındaki eşbütünleşme ilişkileri araştırılmamıştır. iii) Nedensellik testi sonuçlarına göre Kazakistan ve Özbekistan'da elektrik tüketiminden reel gelire doğru, Kazakistan, Türkmenistan ve Özbekistan'da kişi başı reel gelirden elektrik tüketimine doğru nedensellik ilişkisi söz konusudur. Kırgızistan ve Türkmenistan'da ticari açıklıktan reel gelire doğru bir nedensellik ilişkisi söz konusudur. Kazakistan, Kırgızistan ve Özbekistan'da elektrik tüketimi ve ticari açıklıktan kişi başı reel gelire doğru bir nedensellik ilişkisi söz konusudur.

Kazakistan ve Özbekistan'da elektrik tüketiminden reel gelire doğru bir nedensellik ilişkisi mevcut iken, Kazakistan Türkmenistan ve Özbekistan'da ise kişi başı reel gelirden elektrik tüketimine doğru nedensellik ilişkisi söz konusudur. Bu bağlamda Kazakistan ve Özbekistan'da “Geri Besleme Hipotezi” geçerli iken, Türkmenistan'da "Koruma Hipotezi” "nin geçerli olduğu söylenebilir. Bu açıdan Kazakistan ve Özbekistan'da etkin enerji arz ve talep politikalarının oluşturulması, enerji kullanımı ve iktisadi büyüme açısından önem arz etmekte iken, Türkmenistan'da uygulanacak olan enerji tasarruf politikaları iktisadi büyüme üzerinde olumsuz bir etki yaratmaması beklenebilir. Azerbaycan'da ise elektrik tüketimi ve kişi başı reel gelir arasında herhangi bir nedensellik ilişkisi 
olmamakla beraber "Yansızlık Hipotezi" "nin geçerli olduğu söylenebilir. Ayrıca Kırgızistan ve Türkmenistan'da ticari açıklıktan kişi başı reel gelire doğru bir nedensellik ilişkisi söz konusudur. Bu noktada ilgili ülkelerde iktisadi dönüşüm politikalarının desteklenmesi, ekonomik büyümenin teşviki noktasında önem kazanmaktadır.

Diğer taraftan elektrik tüketimi ve ticari açıklık birlikte ele alındığında, Kazakistan, Kırgızistan ve Özbekistan'da elektrik tüketimi ve ticari açıklıktan kişi başı reel gelire doğru bir nedensellik ilişkisi söz konusu olup, elektrik tüketimi ticari açıklık ile beraber ele alındığında "Büyüme Hipotezi" "nin geçerli olduğu söylenebilir. Bu noktada Kırgızistan'da ticari açıklık politikaları ile desteklenen enerji arz ve talep politikalarının iktisadi büyüme üzerinde etkisi olduğu söylenebilir. Son olarak bu üç ülkede, dönüşüm politikaları ile desteklenen enerji arz ve talep politikaları etkin iktisadi büyüme politikaları oluşturmak adına önem kazanmaktadir.

\section{Kaynakça}

Acaravc1, A. (2010), "Structural Breaks, Electricity Consumption and Economic Growth: Evidence from Turkey", Journal for Economic Forecasting, 2, 140154.

Acaravc1, A. ve Özturk, I. (2012), "Electricity Consumption and Economic Growth Nexus: A Multivariate Analysis for Turkey", Amfiteatru Economic, 14(31), 246-257.

Acaravc1, A., Erdoğan, S. ve Akalin G. (2015), “The Electricity Consumption, Real Income, Trade Openness and Foreign Direct Investment: The Empirical Evidence from Turkey", International Journal of Energy Economics and Policy, 5 (4), 1050-1057.

Aktas, C. ve Yilmaz, V. (2008), "Causal Relationship between Electricity Consumption and Economic Growth in Turkey", Zonguldak Karaelmas Üniversitesi Sosyal Bilimler Dergisi, 4(8), 45-54.

Altinay, G. ve Karagöl, E. (2005), "Electricity Consumption and Economic Growth: Evidence from Turkey", Energy Economics, 27(6), 849-856.

Aslan, A. (2013), "Causality Between Electricity Consumption and Economic Growth in Turkey: An ARDL Bounds Testing Approach", Energy Sources Part B: Econ Plan Policy, 9(1), 25-31.

Aslan, A. (2014), "Electricity Consumption, Labor Force and GDP in Turkey: Evidence from Multivariate Granger Causality", Energy Sources, Part B: Economics, Planning, and Policy, 2, 174-182. 
Dünya Bankası, "Dünya Gelişme Göstergeleri Çevrimiçi Veri Tabanı (World Bank World Development Indicators Online Database", http://databank.worldbank.org/data/views/variableSelection/selectvariables.asp $\mathrm{x}$ ? source $=$ world-development-indicators\#) $($ Erişim Tarihi: 10.12.2015).

Erbaykal, E. (2008), "Disaggregate Energy Consumption and Economic Growth: Evidence from Turkey", International Research Journal of Finance and Economics, 20, 1-8.

Jumbe, C. B. L. (2004), "Cointegration and Causality between Electricity Consumption and GDP: Empirical Evidence from Malawi”, Energy Economics, 26(1), 61-68.

Konya, L. (2006), "Export and Growth: Granger Causality Analysis on OECD countries with a panel data approach", Economic Modelling, 23, 978-992.

Kraft, J. ve Kraft, A. (1978), "On the Relationship Between Energy and GNP., Journal of Energy and Development, 3, 401-403.

Ibrahiem, D. M. (2015), "Renewable Electricity Consumption, Foreign Direct Investment and Economic Growth in Egypt: An ARDL Approach", Procedia Economics and Finance, 30, 313-323.

International Monetary Fund (2000), "Transitition Economies: An IMF Perspective on Progress and Prospects", http://www.imf.org/external/np/exr/ib/2000/110300.htm (Erişim Tarihi 05.10.2016).

Im, K. So, Pesaran, M. H., ve Shin, Y. (2003), "Testing for Unit Roots in Heterogenius Panels", Journal of Econometrics, 115, 53-74

Iyke, B. N. (2015), "Electricty Consumption and Economic Growth in Nigeria: A Revisit of the Energy-Growth Debate", Energy Economics, 51, 166-176.

Murray, D. A., ve Nan, G. D. (1996), "A Definition of the Gross Domestic Product Electrification Interrelationship", Journal of Energy and Development, 19, 275-283.

Narayan, P. K., ve Prasad, A. (2008), "Electricity Consumption-Real GDP Causality Nexus: Evidence from a Bootstrapped Causality Test for 30 OECD Countries", Energy Policy, 36(2), 910-918.

Nazlioglu, S., Kayhan, S., ve Adiguzel, U. (2014), "Electricity Consumption and Economic Growth in Turkey: Cointegration, Linear and Nonlinear Granger Causality”, Energy Sources Part B: Econ Plan Policy, 9(4), 315-324.

Pesaran, M. H. (2004), “General Diagnostic Tests for Cross Section Dependence in Panels", http://www.econ.cam.ac.uk/research/repec/cam/pdf/cwpe0435.pdf (Erişim Tarihi: 01.12.2015). 
Pesaran, M. H., ve Yamagata, T. (2008), "Testing Slope Homogenity in Large Panels", Journal of Econometrics, 142, 50-98.

Pempetzoglou, M. (2014), "Electricity Consumption and Economic Growth: A Linear and Nonlinear Causality Investigation for Turkey", International Journal of Energy Economics and Policy, 4(2), 263-273.

Salahuddin, M. ve Alam K. (2016), "Information and Communication Technology, Electricity Consumption, and Economic Growth in OECD Countries: A Panel Data Analysis", Electrical Power and Energy Systems, 76, 185-193.

Smith, L. V., Leybourne, S., Kim, Tae-Hwan, ve Newbold, P. (2004), "More Powerful Panel Data Unit Root Tests with an Application to Mean Reversion in Real Exchange Rates", Journal of Applied Econometrics, 19, 147-170

Soytas, U. ve Sari, R. (2007), "The Relationship between Energy and Production: Evidence from Turkish Manufacturing Industry", Energy Economics, 29, 1151-1165. 